\title{
PROFESOR BARBARA BIEŃKOWSKA
}

Niniejsza książka dedykowana jest prof. dr hab. Barbarze Bieńkowskiej jako wyraz uznania, szacunku i - mający dobrą akademicką tradycję - sposób wyrażenia Jej najlepszych życzeń od kolegów, współpracowników i uczniów.

Profesor Barbara Bieńkowska w swej pracy badawczej obejmuje ważne obszary: dzieje recepcji myśli naukowej, historię książki i księgozbiorów w kontekście ich znaczenia kulturowego, dydaktycznego i społecznego; problemy metodologiczne badań bibliologicznych.

Podstawę dla tak charakterystycznego w Jej twórczości ujmowania przedmiotu badań w szerokim kontekście historycznym i kulturowym stworzyła sobie przez jakże wszechstronne przygotowanie pod kierunkiem mistrzów humanistyki. Studia filologii klasycznej na Uniwersytecie Warszawskim zakończyła przecież pracą magisterską u Kazimierza Kumanieckiego; promotorem Jej stopnia doktorskiego w zakresie historii był Stanisław Herbst.

Wejście na nowe, jeszcze szersze pola badawcze udokumentowała habilitacją w zakresie historii nauki, dając $w$ rozprawie habilitacyjnej wzorcową wprost analizę przenikania nowej doktryny naukowej do szerszej świadomości społecznej (1971). Była już wtedy od dwóch lat pracownikiem naukowo-dydaktycznym na Uniwersytecie Warszawskim, legitymującym się także praktyczną znajomością problematyki bibliotekoznawstwa poprzez dziesięć lat praktyki zawodowej.

W Instytucie Bibliotekoznawstwa i Informacji Naukowej UW czekały Ją rosnące obowiązki i odpowiedzialność na zajmowanych kierowniczych stanowiskach, w tym prodziekana Wydziału Historycznego (1978-1981) i dyrektora Instytutu (19811987). Wielki wkład w kształcenie bibliotekarzy i bibliologów o wysokich kwalifikacjach to - do chwili obecnej - m.in. kierowanie ponad 120 pracami magisterskimi $i$ promotorstwo sześciu doktoratów z dziejów dawnej książki i bibliotek.

Równolegle prof. Barbara Bieńkowska inspiruje i współdziała w zorganizowanych formach krzewienia wiedzy o dawnej ksiażce i troski o należyte przechowanie i wykorzystanie dorobku kulturalnego przeszłości. I w tej działalności towarzyszą Jej nasze najlepsze życzenia. 
